\title{
Population Control of Viruses Insect Vectors in Chili with Plastic Mulch
}

\author{
K.A. Yuliadhi *, T.A. Phabiola and K. Siadi \\ Faculty of Agriculture, Udayana University, Bali, Indonesia \\ *Corresponding author: ayususrusa@yahoo.co.id
}

\begin{abstract}
The incidence of diseases caused by pathogenic viruses in chili is still a major problem in reducing the production of chili in Indonesia. Most agricultural crops are hosts for one or more types of plant viruses, so the virus continued to be a problem in the tropics. Virus is passive, requires intermediaries vector to be transmitted to other plants. The goal of this research was to develop control strategies for aphids that act as a viral vector and pest chili plants using plastic mulch. Control design that was developed in this study based on the habits of local farmers, using plastic mulch with two colors, black and silver. Mulching is done to dispel the arrival aphids into the chili crop, at the same time preventing the emergence of weeds that act as alternative hosts of the virus. The use of silver plastic mulch to control vector viral populations was better compared to black plastic mulch during chili planting. The use of silver plastic mulch can improve yields of chili crops.
\end{abstract}

Keywords: Aphid, whiteflies, Chili chili, virus

\section{INTRODUCTION}

The chili production is still low in Indonesia, which merely $4.35 \mathrm{to} / \mathrm{ha}$, while the potential production are more than 10ton/ha. One of the cause is plant pests that affect from nursery through the post-harvest. Among the plant pests, that most affecting the production of chili is the group of viral pathogens. Viral infection on chili plant reduced between $32-75 \%$ of its production [1] or up to $68.22 \%$ found by Nyana (2012) [2]. The host range of viruses that cause disease in chili is very broad, including intermediate host that can provide a source of inoculum at any time, such as some weeds. Weeds that are growing around chili plants can lead to competitions among the and may also be an alternative host of the viruses [3].

Chili plant virus remains a problem to this day. This is because the source of inoculum available throughout the year, abundance of the vector that are active all the time, and there is no insulation between the gardens. Insects are the most important vectors of plant viruses. There were approximately 700 known species of plant viruses in 1991, which 426 species are transmitted by insects [4]. The species of Aphids have been known to avoid silver reflection of light [5]. The avoidance of silver light by the insects gives us an opportunity to use plastic mulch to plant crops. Control of virus spread was aimed of this study by preventing the contact between infective aphids carry viruses (viruliferous) with chili cultivated plants.
Prevention was done by implementing silver and black plastic mulch.

\section{RESEARCH METHOD}

The research has been conducted at Kerta Village, Payangan, Gianyar Regency. The research was begins with the soil tillage and seed preparation, installation of plastic mulch in the beds, planting, maintaining and harvesting crops. This study was dsesigned in a randomized block design with 3 treatments and 9 replications. All three treatments tested were: 1. Planting virus-free seedlings without mulch (K), 2. Planting virusfree seedlings with silver plastic mulch (MP) and 3. Planting virus-free seedlings with Black plastic mulch $(\mathrm{MH})$. Confirmation of viral infection is done in serological testing by ELISA technique.

Serology detection with ELISA technique was performed using symptomatic plants mosaic with specific antiserum CMV and TMV, while for ChiVMV was using antiserum Universal Potyvirus with DAS-ELISA method following the procedure described in the kit antiserum used (Agdia, USA). Value absorbance was measured at $405 \mathrm{~nm}$ with an ELISA Reader Data was analysed. In order to determine the effect of the treatments given, the observed data was analysed in the analysis of variance (ANOVA), if there was a significant different among treatments $(\mathrm{p} \leq 5 \%)$ observed, further Duncan analysis was conducted. 
III

RESULTS AND ANALYSIS

\section{Apids Population}

Insect virus vector found in this study was the species of aphids and whiteflies, the species of whitefly was Besimia tabaci (Table 1). The average population of aphids and whiteflies changes in accordance with the host plant growth stages of each period of observation. Myzus persicae population at the beginning of the observations increased (Fig. 1), in line with the growth of chili plants and culminated in the observation VI.

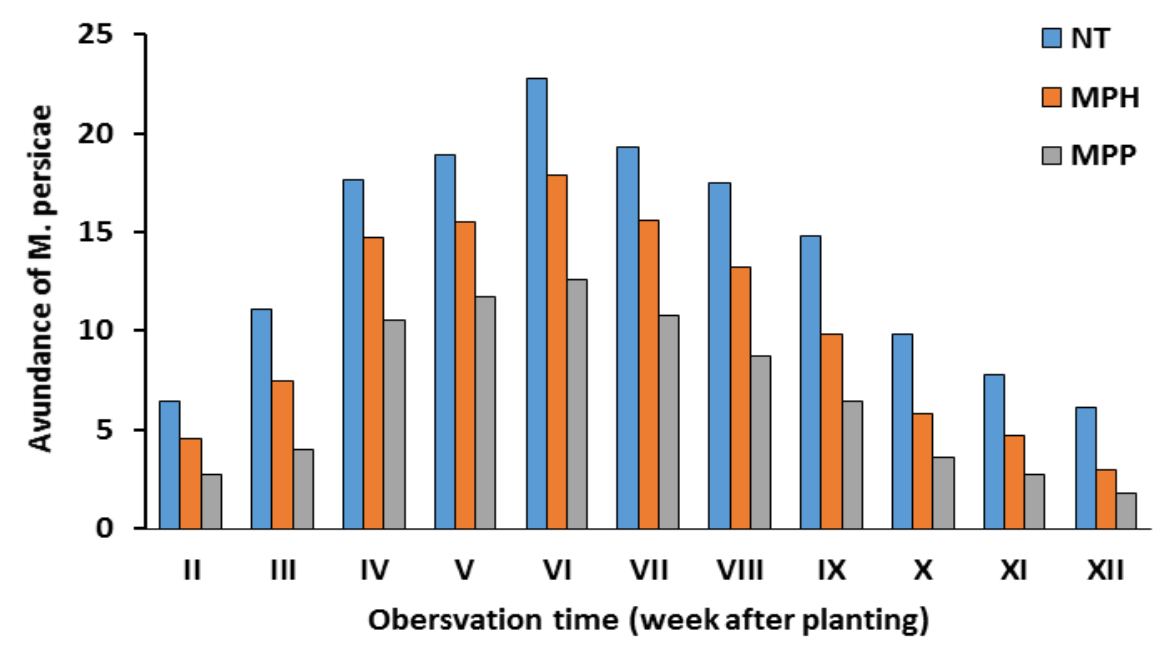

Fig. 1. The average abundance of Myzus persicae at time observation (individuals/plant).

An increase in the population of both species of aphids $M$. persicae and $A$. gossypii from the initial observation period to the highest in the observation period VI, because the chili or chili plant was in peak period of vegetative growth, and the availability of young leaves attract the $M$. persicae and A. gossypii to visit. Young leaves provide food sources for aphids. Aphids can grow optimally when plants sprout [6]. The abundance of $M$. persicae and A. gossypii will decrease when the plant get older or entering the generative period, the plant tissue is tougher and the cell fluid was reduced, so it can support the aphid life. The abundance of aphids I chili crops was closely related to the plnat metabolism activities [7] and the quantity and quality of plant nutrition. Reduction of food supply will affect the abundance of aphids.

The low population of $B$. tabaci population was observed at the beginning of study in chili plantation. In line with the growth of chili plants, the average population of $B$. tabaci has increased and reached its peak in the observation VI, then the presence of $B$. tabaci declined and the lowest when plants at the age of 12 week after planting (Fig. 3).

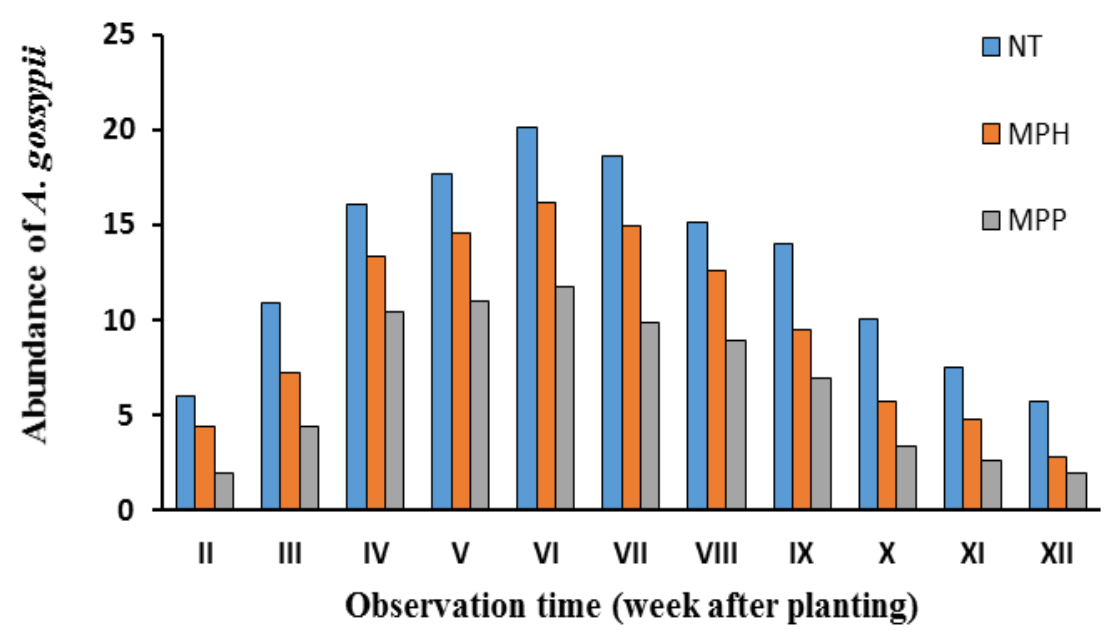

Fig. 2. The average abundance Aphis gossypii at time observation (individuals/plant). 


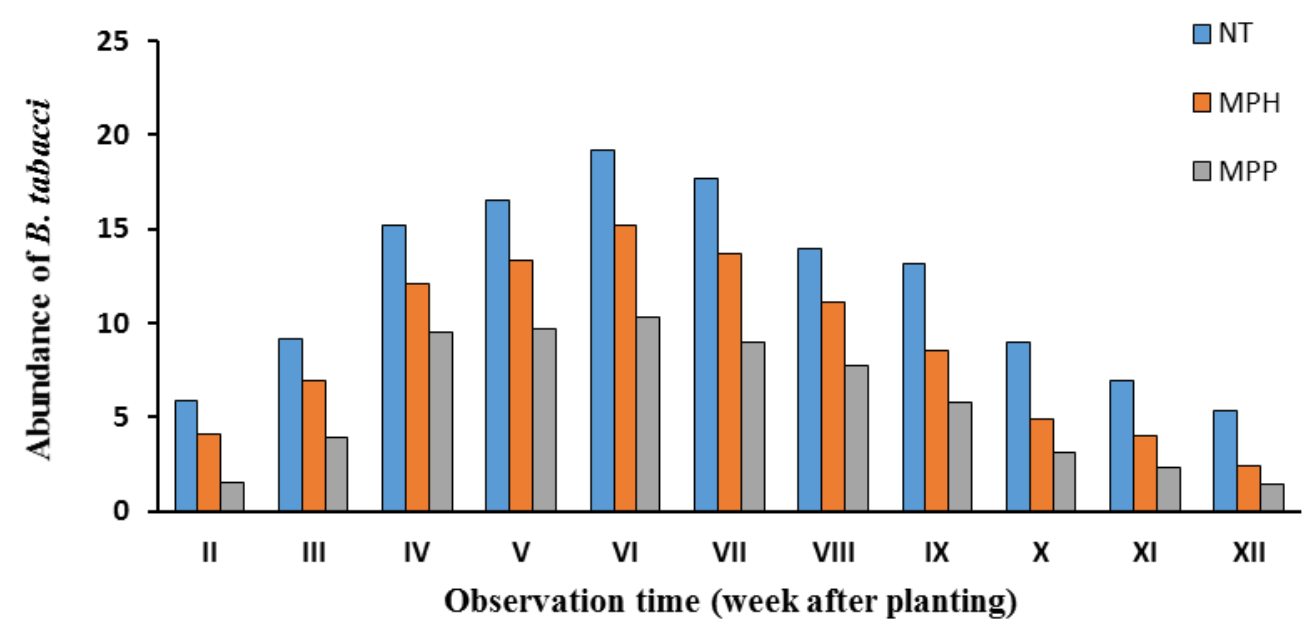

Fig. 3. The average Bemisia tabaci at time observation (individuals/plant).

The population of $B$. tabaci was abundance when chili plants were in vegetative phase, on the observation VI, and decreased in generative phase (algorithmic) on observation XII which may follow the growth of plants.
The quantity of plants can be measured by the number of plant biomass, while the plant quality is depended on various plant nutrition content that are required by insects [8]

TABLE 1.

THE AVERAGE ABUNDANCE OF MYZUS PERSICAE, APHIS GOSSYPII AND BEMISIA TABACI ON OBSERVATION VI

\begin{tabular}{cccc}
\hline Treatments & \multicolumn{3}{c}{ Average abundance (idividuals) } \\
\hline & M. persicae & A. gossypii & B. Tabaci \\
\cline { 2 - 4 } NT & $21.8 \mathrm{a}$ & $22.1 \mathrm{a}$ & $18.4 \mathrm{a}$ \\
MH & $18.9 \mathrm{~b}$ & $15.2 \mathrm{~b}$ & $13.2 \mathrm{~b}$ \\
MP & $11.8 \mathrm{c}$ & $10.9 \mathrm{c}$ & $8.3 \mathrm{c}$ \\
\hline
\end{tabular}

Note: The number followed by different letter in similar column significantly different at the Duncan test at $5 \%$. NT: no treatment/control; MH (black plastic mulch); MP (silve plastic mulch)

Statistical analysis showed that the average population of vector species either $M$. persicae, A. gossypii and $B$. tabaci in silver mulch treatment was significantly different from the population of each vector in black mulch treatment and control. The low average population of each vector of disease-causing viruses on chili plants in the silver mulch treatment because silver has the ability to reflect about 33 percent of near ultra violet light [9], light waves that are favored by most insects, so the insects will follow the direction of reflection and leaving crops [10]. Light reflection is able to reduce the heating effect of rhizosphere under the plastic surface, and the range of light favored by insects, so the insects will follow the direction of reflection and leaving crops. Consequently insect populations act as vectors of diseasecausing viruses can be reduced in the planting area [11]

\section{Virus Disease Symptoms}

The results showed that chili plants in controls (NT) showed symptoms of the virus, wich were higher compared to the treatment of black plastic mulch (MH) and silver plastic mulch (MP), with the symthom of mosaic viruses $(61.7 \%)$, yellow $(21 \%)$ and chlorosis
(9.1\%) at the observation of 10 week after planting (Table 2 ). The average crop with the mosaic virus symtoms was highest in the control treatment, as many as 61 plants was affected. Based on ELISA test results, it was found that CMV-infected plants is the ultimate for all treatments (Table 3).

Based on the result of ELISA test (Table 3), there were several types of viruses associated with mosaic disease in chili ie. CMV, TMV, and ChiVMV. The highest symtoms of virus attack was found in control plant treatments, followed by chili plants treated in black plastic mu;ch and the lowest was in silver plastic mulch (Table 3).

Similar trend was found by Nyana (2012), that the chili with mosaic symptoms were associated with three different virus types, namely Tobacco mosaic virus (TMV), Cucumber mosaic virus (CMV) or Chilean veinal motle virus (ChiVMV). 
TABLE 2.

THE PERSENTAGE OF CHILI PLANTS WITH THE VIRUS SYMTOMS IN EVERY TREATMENT (WITHOUT MULCH/CONTROL, BALCK PLASTIC MULCH AND SILVER PLASTIC MULCH).

\begin{tabular}{|c|c|c|c|c|c|c|c|c|c|}
\hline \multirow{3}{*}{ Treatments } & \multicolumn{9}{|c|}{ The percentage of plant with virus symtoms (week after planting) } \\
\hline & \multicolumn{3}{|c|}{6} & \multicolumn{3}{|c|}{8} & \multicolumn{3}{|c|}{10} \\
\hline & $\mathrm{M}$ & $\mathrm{K}$ & $\mathrm{Kl}$ & M & $\mathrm{K}$ & $\mathrm{Kl}$ & $\mathrm{M}$ & $\mathrm{K}$ & $\mathrm{Kl}$ \\
\hline NT & 32.9 & 8.7 & 6.8 & 45.6 & 12.0 & 8.6 & 61.7 & 21.0 & 9.1 \\
\hline $\mathrm{MH}$ & 9.0 & 5.4 & 3.8 & 14.0 & 8.0 & 4.8 & 23.0 & 14.0 & 6.8 \\
\hline MP & 5.0 & 2.9 & 1.5 & 7.7 & 3.3 & 2.3 & 10.1 & 4.8 & 3.4 \\
\hline
\end{tabular}

Note: NT: control, MH: black plastic mulch, MP: silver plastic mulch, M: mosaic,

$\mathrm{K}$ : Yellow, Kl: Chlorosis

TABLE 3.

THE PERCENTAGE OF VIRUS-INFECTED PLANTS WITH MOSAIC SYMPTOMS OF DAS-ELISA TEST RESULTS OF THE PLANTS ON THE OBSERVATION 10 WEEK AFTER PLANTING

\begin{tabular}{ccccc}
\hline Treatments & $\begin{array}{c}\text { Number of symptomatic } \\
\text { mosaic plant }\end{array}$ & \multicolumn{2}{c}{ Number of virus infected plant* } \\
\hline & Mosaic & CMV & TMV & ChiVMV \\
NT & 61 & 22 & 19 & 19 \\
MH & 23 & 9 & 4 & 8 \\
MP & 10 & 3 & 1 & 2 \\
\hline
\end{tabular}

*The present of the virus base on DAS-ELISA test.

The high percentage of plants symptomatic CMV in each treatment (control, black and silver plastic mulch) is due to this type of virus has a wide range of plant hosts, including the weeds as an intermediate host, so provide source of inoculum all the time. This CMV virus can be transmitted by many aphid species with very high transmission efficacy that also plays a role in spreading the virus [12]. On the other hand, low percentage of virus symptoms in the treatment of silver plastic mulch is due this mulch has the ability to reflect about 33 percent of the sunlight that hits its surface [9], which will put away the insects from the plants toward the reflected light, so escaping plants to be infected by virus carried by the aphids.

\section{Plant Height}

The result shows that chili plant height planted on silver plastic mulch was the highest $(101.05 \mathrm{~cm})$ compared to one that planted in a black plastic mulch $(83.16 \mathrm{~cm})$ and controls $(49.97 \mathrm{~cm})$ (Table 4).

Statistical analysis showed that plant height in the treatment of silver plastic mulch was higher and significantly different to black plastic mulch treatment and control. Plant height seems to be associated with symptoms that appear in an infected plant virus. Chili plants in the control treatment had the lowest average plant height compared to black and silver plastic mulch (Table 4), but the percentage of chili plants attacked by viral disease at control, was the highest among treatments (Table 3). The metabolism of plants that were showing symptoms of viral infection was impaired. The decreased production of growth hormone produced by plants, accompanied by a decrease in the amount of chlorophyll is a common effect that occurs in plants infected by the virus. This will result in disturbance of plant growth, therefore plant height [13].

TABLE 4.

PLANT HEIGHT, NUMBER OF BRANCHES AND YIELD (TONS/HA) OF CHILI PLANTS PLANTED IN THREE DIFFERENT TREATMENTS (NT: NO TREATMENT OR COMTROL; MH: BLACK PLASTIC MULCH AND SILVER PLASTIC MULCH).

\begin{tabular}{lccc}
\hline Treatment & Plant height $(\mathrm{cm})$ & Number of primary branch & $\begin{array}{c}\text { Yield } \\
\text { (ton/ha) }\end{array}$ \\
\hline NT & $49.97 \mathrm{c}$ & $10.92 \mathrm{~b}$ & $4.87 \mathrm{c}$ \\
MH & $83.16 \mathrm{~b}$ & $14.6 \mathrm{a}$ & $8.89 \mathrm{~b}$ \\
MP & $101.05 \mathrm{a}$ & $14.8 \mathrm{a}$ & $12.43 \mathrm{a}$ \\
\hline
\end{tabular}

Note: Number followed by the same letter in the same column showed no effect among treatments on Duncan test at $5 \%$. 


\section{Number of Primary Branches}

The highest average number of primary branches produced was from chili planted in the silver plastic mulch (14.8), followed by black mulch treatment (14.8) and the lowest was in control treatment (10.92). Statistical analysis shows that the average number of primary branches produced was not significantly differ between chilis planted in silver and black plastic mulch, but with control treatment (Table 4). Metabolic processes in the vegetative period greatly affects the process by which plants entering the generative period [13]. Effect of plastic mulch on the growth and yield determined by the balance of the light that hits the surface of the plastic used.

In general, the sunlight that hits the surface of the silver mulch, large proportion will reflected back, and only a small portion is absorbed, transmitted and reaches the ground surface, while all light that hits black plastic mulch is absorbed. The capability of the plastic mulch in reflecting, absorbing and passing the light is determined by the color and the thickness [14][15][16]. Light reflected from the surface of the plastic mulch affects the lower surface of leaves of the plant, so that the light distributed evenly for photosynthesis, while the light transmitted into the subsurface plastic mulch will affect the physical, biological and chemical of the rhizosphere covered. Sunlight that passed across the surface of mulch stuck in the ground and form a greenhouse effect in a small scale [17][18]. Increasing number of primary branches per plant affect the amount of flowers formed per plant. The more primary branches are produced, more flower also formed from the axial of the branches [19].

\section{Yields}

Similar to the number of primary branches produced, the yields were significantly higher in chili plants growing in silver plastic mulch (12.43 ton/ha), compared to black plastic mulch (8.89 ton/ha) and control $(4,87$ ton/ha) (Tabel 4). Plastic mulch has several advantages, such as it has effectiveness in protecting the soil from exposure of direct raindrops, preventing splash of soil onto the plant, preventing the nutrient leaching, maintaining soil porosity, slowing the release of soil carbon dioxide from respiration activity of microorganisms, maintain soil temperature, prevent soil water evaporation, and maintain soil organic matter content. Mulch also has important function to control the growth of weeds, which is the main competitor in of plant to gain nutrient from soil. Weeds has been found as the host of the virus, as well as has the ability to suppress viral vector insect populations [20], therefore viral infection of the plant. As a result, chili plants were well growing, indicated by increasing plant heights, number of primary branches and yeilds.

Low yileds from control plants related to high number of plants were infected by viruses at the beginning of growing phase. Low amount of growth hormone was produced in plants infected by viruses, which are accompanied by a decrease in the amount of chlorophyll. This leads to disruptions in plant growth that directly affects the yileds [13]. The use of plastic mulch affects microorganisms activity (as a result of increases rhizosphere temperature), which are contributing to the growth and yield by increasing carbon dioxide concentrations in the planting zone [11] and the supply mocro organic matter [21]. Dark-colored plastic mulch is very effective in controlling weeds [9]. This happens because the seeds of weeds under black plastic mulch has no access to sunlight for photosynthesis, so the weeds will experience etiolation and grow weaker. This weak growth will be exacerbated by the relatively hot temperatures and high soil moisture.

Hot and high moisture enviroment has a higher lethal effect to the weeds than dry heat. Other studies also found that the use of black-silvered plastic mulch consistently effective in suppressing the growth of weeds, where the weed is a major competitor of the plant in taking water and nutrients [20][22][23][24]. The advantages of the use of silver plastic mulch in producing the highest yields compared to black plastic mulch and control (no treatment), was related to its ability in reducing pest populations in chili plants, and indirectly able to reduce the incidence of viruses [20]. This is because the pests were served as vectors of the viruses [25], where indirectly, the use of silver plastic mulch can suppress viral disease, resulted in plants were growing better, so increase plant resistance [11].

Another advantage of the use of silver plastic mulch is that, it is able to reflect light so it does not illuminate the ground directly. The increasing amount of light that plants cought will increase the photosynthesis, resluts in higher carbohydrate produced [26].

This is in accordance with Harjadi (1993) who found that the amount carbohydrates will affect the size of the cell formed, because the carbohydrates produced from photosynthesis will be used in the process of cell division and enlargement of the fruit.

\section{CONCLUSION}

The use of silver mulch in chili crops was found the best in controlling insect viral vector compared to black plastic mulch and control, and increased in crop yields.

\section{ACKNOWLEDGMENT}

This study was funded by Udayana University with Letter of Agreement No.: 6417/UN14.2PNL.01.03.00/2016, dated 15 th June 2016.

\section{REFERENCES}

[1] Sulyo, Y. 1984. Penurunan Hasil Beberapa Varietas Lombok akibat Infeksi Cucumber Mosaic Virus (CMV) di Rumah Kaca. Laporan Hasil Penelitian, Balai Penelitian Hortikultura Lembang 1982/1983.

[2] Nyana, D.N. 2012. Isolasi dan Identifikasi Cucumber Mosaic Virus Lemah untuk Mengendalikan Penyakit Mosaik pada Tanaman Cabai (Capsicum frutescens L.). Disertasi. Program Studi Ilmu Pertanian Program Pascasarjana Universitas Udayana. Denpasar. 
[3] Moenandir,J. 2010. Ilmu Gulma. Malang: Universitas Brawijaya Press.

[4] Frankci, R.I.B., Fauquet, C.M., Knudson, D.L. and Brown, F 1991. Clasifica-tion and Nomenclature of Viruses. 5th report of the International Com-mittee on Taxonomy of Viruses. Archives of Virology 2. New York: Springer.

[5] Blackman, R.L. and V.F. Eastop. 2000. Aphids on the World's Crop. An identification and Information Guide, 2nd Eds. New York: John Wiley and Sons.

[6] Ditlin. 2008. Kutu Daun (Myzus persicae). Available: http://ditlinhor tikultura.go [11 Juni 2013].

[7] Kennedy, J.S. and H.L.G. Stroyan. 1959. Biology of Aphid. Ann. Rev. Entomol. 4:139-160.

[8] Heinz, K. M., M. P. Parella and J.P Newman., 1982. Time Effecient Used Of Yellow Sticky Trap In Monitoring Insect Population. J. Economic Entomology 85:2263-2269.

[9] Fahrurrozi and K.A. Stewart. 1994. Effects of mulch optical properties on weed growth and development. HortScience 29(6):545.

[10] Kring, J.B. 1964. New Ways to Repel Aphids. Frontier of Plant Science 17:6-7.

[11] Fahrurrozi, K.A. Stewart and S. Jenni. 2001. The early gowth of musk melon in mulched mini-tunnel containing a thermal-water tube. I. The carbon dioxide concentration in the tunnel. J. Amer. Soc. For Hort. Sci. 126:757-763.

[12] Escriu, F., K. L. Perry, and F. Garcia-Arenal. 2000. Transmissibility of Cucumber Mosaic Virus (CMV) by Aphis gossypii Correlates with Viral Accumulation and is Affected by the Presence of its Satellite RNA. Phytophathology 90:1068-1072.

[13] Agrios, G.N. 2005. Plant Pathology. $5^{\text {th }}$ Ed. New York: Academic Press.

[14] Decouteau, D.R., M.J. Kasperbauer, D.D. Daniels and P.G. Hunt. 1988. Plastic mulch color effects on reflected light and tomato plant gowth. Scientia Hortic.34:169-175.
[15] Lamont, W. J. 1993. Plastic Mulches for the Production of Vegetable Crops. HorTechnology 3(1):35-38.

[16] Tanner, B. 1974. Microclimate Modifica-Tion: Basic Concepts. HortScience 9:555-560

[17] Mahrer, Y. 1979. Prediction of Soil Temperatures of A Soil Mulched with Transparent Polyethylene. J. Applied Meteorology 18:1263-1267.

[18] Evan, L.T. 1975. The Physiology basis of yield. Crop Physiologi. Cambridge University Press.

[19] Fahrurrozi. 1995. Pengaruh Mulsa Plastik terhadap Pertumbuhan dan Hasil Paprika (Capsicum annuum L.) Jenis Bell dan Populasi Aphid. Jurnal Penelitian Universitas Bengkulu 2(4):1-8.

[20] Hill, D.E., L. Hankin, and G.R. Stephens. 1982. Mulches: Their effect on fruit set, timing and yield of vegetables. Conn. Ag. Exp. Sta. Bulletin.805.

[21] Schonbeck, M.W. 1998. Weed Suppres-sion and Labor Costs Associated with Organic, Plastic and Paper Mulches in Small Scale Vegetable Production. J.Sustain.Agric. 13:13-32.

[22] Setyowati, Nanik, Fahrurrozi, P. Prawito, dan E. Satria.2003. Pertumbuhan dan Hasil Kentang Dataran Tinggi Rejang Teknik Pemulsaan dan Pemupukan Bokashi terhadap Pertumbuhan Gulma. Pros. Konf. Nas. HIGI XVI. Bogor, Juli 2003.

[23] Fahrurrozi, N. Setyowati, dan Sarjono. 2006. Efektifitas Penggunaan Ulang Mulsa Plastik Hitam Perak dengan Pemberian Pupuk Nitrogen terhadap Pertumbuhan dan Hasil Cabai. Bionatura 8:17-23.

[24] Wyman, J.A., N.C. Toscano, K. Kido, H. Jhonson, and K.S. Mayberry. 1979. Effects of Mulching on The Soread of Aphid-Transmitted Watermelon Mosaic and Virus to Summer Squash. J. Eco. Entomol. 72:139-143.

[25] Junaidi, M., S.J. Santosa, dan E.S. Sudalmi. 2013. Pengaruh Macam Mulsa dan Pemangkasan Terhadap Pertumbuhan dan Hasil Tanaman Semangka (Citrullus vulgaris schard). J. Inovasi Pertanian 12 (2). 